Jurnal Pendidikan Malaysia 40(1)(2015): 83-88

\title{
The Demands and Influence of Leadership on Educational Changes
}

\author{
(Tuntutan dan Pengaruh Kepemimpinan terhadap Perubahan Sistem Pendidikan)
}

\author{
Siva RABINDARANG*, KHUAN WAI BING \& KHOO YIN YiN
}

\begin{abstract}
Education system is facing changes due to the demands and current situation. This change includes the delivery and productivity improvements. Leadership is an important factor in the implementation of the changes. Leaders play an important key role in ensuring the success of the changes in the education system. Leaders serve as a liaison and facilitator within the organization. Therefore, leaders should adopt appropriate leadership style to face educational changes. Distributed leadership proposed in the field of leadership studies to be able to improve organizational effectiveness. Distributed leadership is the leadership appropriate to the performance of the changes in the education system. This article discusses previous studies on demands and influence of leadership on the education changes system particularly distributed leadership.
\end{abstract}

Keywords: Changes; leadership; distributed leadership; leaders; education

ABSTRAK

Sistem pendidikan sedang menghadapi perubahan secara terancang disebabkan oleh tuntutan dan keadaan semasa. Perubahan ini meliputi peningkatan sistem penyampaian dan produktiviti kerja. Aspek kepemimpinan adalah faktor yang penting dalam pelaksanaan perubahan. Pemimpin bertindak sebagai penasihat dan juga fasilitator dalam organisasi. Justeru itu, pemimpin perlu mengamalkan kepemimpinan yang bersesuaian dengan pelaksanaan perubahan dalam sistem pendidikan. Kepemimpinan teragih diketengahkan dalam peningkatan keberkesanan organisasi. Kepemimpinan teragih bersesuaian dengan pelaksanaan perubahan sistem pendidikan. Artikel ini mengupas kajian-kajian lepas tentang tuntutan dan pengaruh kepemimpinan terhadap perubahan dalam sistem pendidikan khususnya kepemimpinan teragih.

Kata kunci: Perubahan; kepemimpinan; kepemimpinan teragih; pemimpin; pendidikan

\section{INTRODUCTION}

Today's education system is facing changes due to requirement and demands. This change is in the line with the development of science and technology. Governments play a very important role in educational changes. Education had undergone many changes with the development of national policies. National policies expand due to the improvement to ensure the needs of people (Mior 2011). The aim of education changes is to improve the quality of education (Abd. Ghafar 2011). The task of education changes is the responsibility of all who involve in the education system. The implementation of changes will alter the structure of programmes or practice to better than previous (Mohd Izham \& Norzaini 2009). With this, organizations can achieve the goals and targets. Table 1 is about the changes and development in Malaysia education system. According to the Table 1, Malaysia's education system facing changes and transformation consequently. These changes due to the new policies and era. All the changes in the education system are to make the system more effective and reliable to the current situation.

Success is an important indicator in the implementation of changes. This is because, the effectiveness and improvement of an organization judged according to the success achieved. According to Abd. Ghafar (2011) success can be achieved based on the effectiveness action rather than modern infrastructure and technology. Success can be achieved with the action and cooperation among all stakeholders in the organizations. With this implementation of changes in the education system, the action and support of all parties are needed to achieve the success.

Implementation of change is a process that requires the support and cooperation of all parties in achieving success. This process requires that relevant leadership style to achieve the desired success. Leadership is an important aspect of an organization to achieve the goals, vision, mission and objectives of the organization (Baharom \& Mohamad Johdi 2009). This leadership style can influence others to achieve organizational goals. Leaders are the person carriers of changes to the organization (Jamil 2012). Leadership style is dependent on the capabilities and leadership skills in leading organizations. Implementation of changes and transformation in the education system made a significant impact on the relationship between leadership effectiveness with educational institutions (Cheah 2008). These shows there are strong relationship between leadership and organization. According to Ahmad 


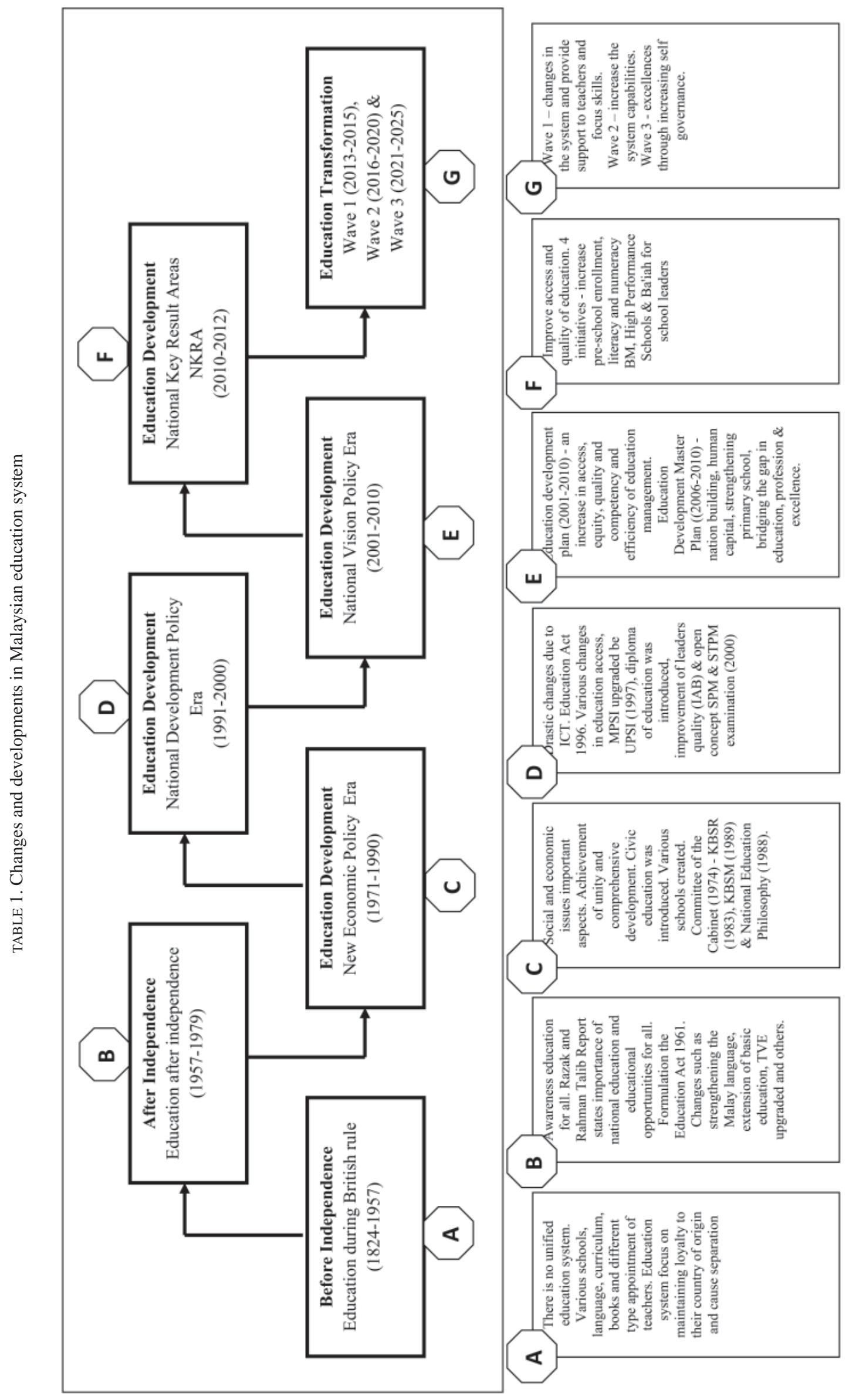


Badrul dan Nik Azida (2010), leadership is an important component and is often neglected in the effectiveness and quality of educational outcomes in recent years. Leadership effectiveness depends on the method and its implementation on the employee. Therefore, leadership should be acceptable and beneficial for organization to increase organizational effectiveness.

\section{LEADERSHIP EXPECTATION AND REQUIREMENTS}

Organizations require different leadership than before. The aim, to keep pace with developments and current demands. High demands on the leadership and leaders have to deal with various changes and challenges (Cairnes 2012). Field leadership increasingly important and challenging than ever before (Coates et al. 2012; Martin 2007; Hernez-Broome \& Hughes 2004). Therefore, leaders need to face the changes and challenges with a different leadership style than ever before. This leadership must be suited to the current needs of the organization.

Demands and challenges of leadership is due to the changes that constantly occur within the organization. Changes in the organization always occur due to expectations, competition and latest requirements. Changes that occur are complex, fast and difficult to predict (Petrie 2011). Roles and responsibilities of leaders is also changing due to current changes (Abu Nayeem 2011). With this, organizations need leaders who are capable and suitable to change (Petrie 2011; Jamaluddin et al. 2010; Baharom \& Mohamad Johdi 2009; Kamarol \& Johan 2011). Leaders should play an 'extraordinary' in leadership to keep pace with changes in the organization. Leaders must also be sensitive to the changes and ensure the successful implementation (Majid 2011).

Leadership is an important process in the organization. Leadership is a complex process (King 1990; Bolden et al. 2003; Jackson 2003; Antonakis et al. 2004; Avolio et al. 2009; Sharon et al. 2010; Abu 2011; Day \& Antonakis; 2012) and specific definition of leadership does not exist and cannot be obtained. The success of an organization is determined by the style of leadership that influence an organization. Leadership effectiveness is determined by the traits and behaviors of a leader (Jamil \& Norlia 2008). Leadership style is also defined through behavior by a leader (Casimir \& Yong 2010). A leader must have skills in the operation and implementation of the organization (Jogulu 2010). A leader is very important personnel in changing and monopolizing an organization. Therefore, leaders must have the skills and behaviors that can increase the effectiveness of an organization.

Presently, many organizations use alternative leadership rather than structured hierarchy style. The alternative leadership styles are team leadership and shared leadership (Gordon \& Yukl 2004). Leaders in the organization must respond to the new challenges of diversity, distribution forms of organization, globalization, rapidly changing environment, multi-tasking and new working arrangements. Effectiveness and school improvement currently require renewal in leadership style (Cheah et al. 2011). This style is different from the topdown, hierarchical, and autocratic lengthy bureaucratic procedures. Cheah et al. (2011) also noted the increasingly complex educational needs knowledge workers, skilled and competent in making all leadership functions. In this situation, the function requires partnership and division leadership accountability and authority in ensuring the effectiveness of the organization.

Leadership role in the education system are planning, monitoring, and evaluation. But now the role has been broadened to motivate, increase positive behavior and teamwork coordination among the workers (Taliadorou \& Pashiardis 2011). School performance cannot rely on the principle leadership only and there should be full participation of the teachers and students in particular (Loh 2008). School administrators are also responsible for polishing and building the capacity of teachers in all areas especially the leadership. In this way, organizations can achieve greater efficiency and at a high level. This concept refers to sharing and devolution of power that enable teachers to participate in school leadership. In this case, the changes of leadership in organizational hierarchy system become thin (Taliadorou \& Pashiardis 2011; Jogulu 2010). Elements of communication and interaction are an important element in facilitating sharing and devolution of power (Atwood et al. 2010). Organization's success is influenced by the style of leadership education in partnership and provides opportunities for employees to participate in the leadership.

\section{LEADERSHIP RELATIONSHIP WITH CHANGES IN THE EDUCATION SYSTEM}

Education is facing changes comprehensively and well organized. The education system in Malaysia is undergoing a radical changes began around the year 1990's (Habib 2008). Changes in the education system are caused by the policies and context (Bolivar-Botia \& Bolivar-Ruano 2011; Muhammad Faizal et al. 2011). These changes are inevitable as demand is increasing. With this, the leader's role is to ensure that changes in the education system runs smoothly. These changes cause a variety of reactions and work situations existence within the organization. The work situations that often discussed are job satisfaction, motivation, job stress and organizational commitment. These work situations can lead to success or not. Many studies have been done to identify correlation leadership and work situations. However, these studies should be always conducted due to the developments in the leadership field.

Work situations in the organization can influence the organization effectiveness. Leaders play an important role in the organization (Akhtar 2012). With this, the leadership should be appropriate to the situation and needs of the organization (Lokman et al. 2008). Leadership influences 
motivation, satisfaction and organizational commitment (Lokman et al. 2008; May-Chiun et al. 2009). High motivation and commitment in organizations is one of the important work situations to solve complex problems in the organization (May-Chiun et al. 2009). Thus, the leadership should be more democratic and acceptable in the organization. It is because leadership style is an important aspect influencing work situation in the organization.

The current demand and changes can cause varieties of problems in the organization. Job stress is one of the work situations that increasing due to high demands (Martin 2007). This condition can cause health problems, decreased performance and depression. As the solution to the problem, leaders need to create a sense of teamwork, good relationships and collaborative work patterns (Davey 2012). This is because the current demands the leader to create the space and opportunity for others to participate in the organization. Leaders need to implement high regard and establish a friendly relationship with employees. This situation will affect the performance of work effective, efficiency and suitable with the changes.

Leadership demands are different than before. Now it is necessary the leadership should oriented decentralization, collaborative, non-hierarchical and centralized in education field. Studies on leadership and organizational commitment is still lacking in the country (Lokman et al. 2008; MayChiun et al. 2009).

\section{DISTRIBUTIVE LEADERSHIP AND RELATIONSHIP WITH THE EDUCATION SYSTEM}

Organizations need caliber and dynamic leaders in achieving success. Leaders need to adapt to the situation and current needs. The improvement and changes should accordance with the current situation. Hierarchical leadership system is now less interest and no longer practical. Formal hierarchical structure leadership processes are difficult in organizations (Hulpia \& Devos 2009). Therefore, the teamwork leadership form is important in today's organizations. The teamwork leadership can enhance work effectively (Ministry of Education 2012).

Distributive leadership is the current leadership that gaining attention in educational organizations. Distributed perspective includes interaction between leaders, followers and situations (Hulpia \& Devos 2009). According to Harris and Spillane (2008) the model of distributed leadership focuses on the interaction in the organization. Distributed leadership is no longer seen as the individual work but teamwork (Hulpia et al. 2010). Hulpia et al. (2010) studies shows, support and cooperation dimensions in distributed leadership increase organizational commitment among employees. Therefore, it will enhance the role and accountability among employees (Angelle 2010). Employees feel more eager to be involved and contribute to the implementation of the decisions of the organization (Harris 2012). However, empirical studies of distributive leadership are still lacking and not comprehensive (Larry
2003; Mayrowetz 2008; Angelle 2010; Hulpia \& Devos 2009; Hulpia et al. 2010). Now, distributive leadership is gaining the attention and many researchers began to explore this type of leadership.

Today's educational leadership trend is different from before. Principals can no longer assume all responsibilities as school leaders (Rosnarizah 2009). Success and failure depends on the ability of school principals leading the staff (Latif 2007). Distributive leadership is able to reduce the gap between leaders and employees. With these; problems related to teaching and learning can be overcome (Gronn 2008). Therefore, implementation of the suitable leadership should be in line with current needs. Education Development Plan 2013-2025 of the Ministry of Education Malaysia recommended that distributive leadership should be incorporated in the national education system (Ministry of Education 2012). The aim is to enhance the leadership model that better quality and best practice in education. With this, the leadership will achieve high levels of performance and consistent with current demands.

\section{CONCLUSION}

The education system is becoming a complex and undergone significant transforms with the changes of times. The needs and demands of education in the 21's era require a robust administrative system. There is need of new type leadership to suit the current changes and changes in educational system. Distributive leadership is current type of leadership that is gaining attention in educational organizations. Moreover, leadership distribution able increase job satisfaction and work commitment in organization. These shows there are good relationship among leaders and workers which give positive impacts for the organization effectiveness. However, previous research shows that empirical study of distributive leadership is still lacking and not comprehensive. Therefore, the relevance and further studies on distributive leadership are needed in the education system.

\section{REFERENCES}

Abd. Ghafar Mahmud. 2011. Haluan Kerja Pendidikan: Merealisasikan Agenda Transformasi Negara. Kementerian Pelajaran Malaysia.

Abu Nayeem Mohammad Salahuddin. 2011. Perceptions of Effective Leadership in Bangladesh Secondary Schools: Moving towards Distributed Leadership? Thesis of Master of Education. College of Education University of Canterbury Christchurch, New Zealand.

Ahmad Badrul Shah Raja Hussin Nik Azida Abd Ghani. 2010. Pengaruh Kepemimpinan Etika Ketua Jabatan Terhadap Penglibatan Kerja Pensyarah dan Peranan Tanggapan Sokongan Organisasi. Prosiding Seminar Transformasi Pendidikan Teknikal; Penyelidikan dan Pendidikan dan Kepemimpinan Pentadbiran My TED 10'.

Akhtar, S. 2012. The relationship of managers leadership styles with gender, experience and socio-economic status: an 
analysis of banking sector organizations. International Journal of Modern Management Sciences 1(1): 1-13.

Angelle, P.S. 2010. An organizational perspective of distributed leadership: A portrait of a middle school. National Middle School Association 33(5).

Antonakis, J., Cianciolo, A.T. \& Sternberg, R.J. 2004. Leadership: past, present, and future. Thousand Oaks. CA: Sage Publications.

Atwood, M.A., Mora, J.W. \& Kaplan, A.W. 2010. Learning to lead: evaluating leadership and organizational learning. Leadership \& Organization Development Journal 31(7), 576-595.

Avolio, B.J., Walimbwa, F O. \& Weber, T.J. 2009. Leadership: current theories, research, and future directions. Annu. Rev. Psychol. 60:421-49.

Baharom Mohamad \& Mohamad Johdi Salleh. 2009. Kepimpinan pendidikan dalam Pembangunan Modal Insan. Prosiding “Seminar Pembangunan Modal Insan 2009”, Kecemerlangan Modal Insan. Pusat Sumber Pendidikan Negeri, Pengkalan Chepa, Kota Bharu Kelantan.

Bolden, R., Gosling, J., Marturano, A. \& Dennison, P. 2003. A Review of Leadership Theory and Competency Frameworks. Report for Chase Consulting and the Management Standards Centre, Centre for Leadership Studies, University of Exeter, UK.

Bolívar-Botía. A. \& Bolívar-Ruano, R. 2011. Schools Principals in Spain: from Manager to Leader. International Journal of Education 3(1): E5.

Cairnes, M. 2012. Leadership competence. Leadership Excellence 29(11): 19-20.

Casimir, G. \& Yong, N.K.N. 2010. Combinative aspects of leadership style and the interaction between leadership behaviors. Leadership \& Organization Development Journal 31(6): 510-517.

Cheah, L, Abdul Ghani Kanesan Abdullah, Aziah Ismail \& Naser Jamil Alizydeen. 2011. How democratic leaders empower teachers job satisfaction? The Malaysian case. International Journal of Business and Social Science 2(10): 251-257.

Cheah, L. (2008). The impact of principal's CHANGESal democratic leadership style on teachers' job satisfaction and commitment. Thesis, Universiti Sains Malaysia.

Davey, L. 2012. Vital teams start building your own. Leadership Excellence 29(11).

Day, D.V. \& Antonakis, J. 2012. The Nature of Leadership; Leadership: Past, Present and Future. SAGE Publications, Inc.

Gordon, A. \& Yukl, G. 2004. The future of leadership research: Challenges and opportunities. German Journal of Human Resource Research 18(3): 359-365.

Gronn, P. 2008. The future of distributed leadership. Journal of Educational Administration 46 (2): 141-158.

Habib, M.S. 2008. Globalisasi dan cabaran pendidikan di Malaysia. Masalah Pendidikan 31(1): 91-101.

Harris, A. \& Spillane, J. 2008. Distributed leadership through looking glass. Management in Education BELMAS 22(1): 31-34.

Harris. A. 2012. Distributed leadership: Implications for the role of principal. Journal of Management Development 31(1): 7-17.

Hernez-Broome, G. \& Hughes, R.L. 2004. Leadership Development: Past, present and future. Human Resource Planning 27(1): 24-32.
Hulpia, H. \& Devos, G. 2009. Exploring the link between distributed leadership and job satisfaction of school leaders. Educational Studies 35(2): 153-171.

Hulpia, H., Devos, G. \& Keer, H.V. 2010. The influence of distributed leadership on teacher's organizational commitment: A multilevel approach. The Journal of Educational Research 103(1): 40-52.

Hulpia, H., Devos, G. \& Rosseel, Y. 2009. Development and validation of scores on the distributed leadership inventory. Educational and Psychological Measurement 69(6): 10131034.

Jabor, M.K., Minghat, A.D., Maigari, S.A. \& Buntat, Y. 2012. Sustainable leadership for technical and vocational education and training in developing nations. International Journal of Scientific and Research Publications 2(8): 1-5.

Jackson, D. 2003. Distributed Leadership 'Spaces between the Pebbles in the Jar'. Notthingham: The National College for School Leadership, Nottingham.

Jamaluddin Hashim, Baharom Mohamad, Kamarolzaman Md. Jidi, Ramlan Zainal Abidin \& Hussein Junoh. 2010. Leadership in technical and vocational education. Journal of Technical Education and Training: 49-66.

Jamil Adimin. 2012. Kepimpinan untuk Pembelajaran: Belajar Memimpin Diri untuk Membawa Perubahan. Seminar nasional kepimpinan dan pengurusan pendidikan kali ke-19, Institut Aminudin Baki, Kementerian Pelajaran Malaysia.

Jamil Ahmad \& Norlia Goolamally. 2008. Atribut Pemimpin Sekolah ke Arah Kelestarian Kepimpinan: Satu Faktor Analisis. Prosiding Seminar Nasional Pengurusan dan Kepimpinan Pendidikan kali ke-18, 24-35. Institut Aminudin Baki, Kementerian Pelajaran Malaysia.

Jogulu, U.D. 2010. Culturally-linked leadership styles. Leadership \& Organization Development Journal 31(8): 705-719.

King, A.S. 1990. Evolution of leadership theory. National Social Science Documentation Centre Indian Council of Social Science Research 15(2): 43-54.

Larry, L. 2003. Distributed leadership. Research Roundup 19(4): Summer. Available: http://eric.uoregon.edu/publications/ roundup/Summer_2003.html.

Latif Muhammad. 2007. Pelaksanaan Kepemimpinan Pengajaran di Kalangan Pengetua Sekolah. Seminar Penyelidikan. Institut Penguruan Batu Lintang Tahun.

Loh, K.C. 2008. Kepimpinan guru (teacher leadership) di sebuah Sekolah Menengah Kerajaan di Papar: Kes SMK Majakir. Jurnal Munsyi, Edisi Perdana 1.

Lokman Mohd Tahir, Hamdan Said, Rosni Zamuddin Shah Sidek, M. Al-Muzammil Yassin \& Sanitah Mohd Yusof. 2008. Analisis Kepemimpinan Pengetua Sekolah Menengah di Johor. Research Vote No: 78279, Universiti Teknologi Malaysia.

Majid Farahani. 2011. An exploration of the relationship between transformational leadership and organizational commitment: The moderating effect of emotional intelligence: Case study in Iran. International Business Research 4(4): 211-217.

Martin, A. 2007. The future of leadership: where do we go from here? Industrial and Commercial Training 39(1): 3-8.

May-Chiun, L., Ramayah, T. \& Hii, W.M. 2009. Leadership styles and organizational commitment: latest on Malaysia manufacturing industry. African Journal of Marketing Management 1(6): 133-139.

Mayrowetz, D. 2008. Making sense of distributed leadership: exploring the multiple usages of the concept in the field. Educational Administration Quarterly 44(3): 424-435. 
Ministry of Education. 2012. Pelan Pembangunan Pendidikan Malaysia 2013-2025. Laporan Awal. Kementerian Pelajaran Malaysia.

Mior Khairul Azrin. 2011. Sistem pendidikan di Malaysia: Dasar, cabaran dan pelaksanaan ke arah perpaduan nasional. Sosiohumanika 4(1): 33-48.

Mohd Izham Mohd Hamzah \& Norzaini Azman. 2009. Pandangan pentadbir terhadap implementasi proses perubahan terancang pada sekolah bestari di Malaysia. Sosiohumanika 2(1): 75-88

Mohd Izyan Zuhaili Zainudin, Muhammad Sukri Saud \& Mohd safari Nordin. 2012. Curriculum in TVET: catalyst towards nations's success. Journal of Technical, Vocational \& Engineering Education 5: 20-27.

Muhammad Faizal A. Ghani, Mohd. Rofidzan Abd. Manap, Norfariza Mohd. Radzi, Saedah Siraj, Mohd Helmee Firdaus Salehudin, Shahril@Charil Marzuki \& Faisol Elham. 2011. Kepimpinan Pengetua Aliran Akademik dan Agama: Satu Kajian Awal. Prosiding Seminar Majlis Dekan-dekan Pendidikan IPTA 2011, 1237-1268.

Nurul Nadya Abu Bakar, Rohana Hamzah \& Amirmudin Udin. 2011. Cabaran-cabaran dalam pendidikan teknik dan vokasional dalam membangunkan sumber manusia. Journal of Edupres 1: 159-164.

Siva a/l Rabindarang*, Khuan Wai Bing \& Khoo Yin Yin Faculty of Management and Economics

Universiti Pendidikan Sultan Idris

Perak

Corresponding author*; email: siva_smtsr@yahoo.com

Received: 1 July 2013

Accepted: 3 November 2014
Petrie, N. 2011. Future trends in leadership development. A White Paper. Retrieved from Nicholas Petrie website: http://www. nicholaspetrie.com/wpcontent/uploads/2012/01/futuretrends-in-leadership-development1.pdf.

Rosnarizah Abdul Halim. 2009. Kajian Eksplorasi Distributed Leadership di Malaysia. Seminar Nasional Pengurusan dan Kepemimpinan Pendidikan ke-16, Institut Aminuddin Baki.

Seters, D.A. \& Field, R.G. 1990. The Evolution of Leadership Theory. Journal of Organizational Change Management 3(3): 29-45.

Sharon, C.P., Jefferson, D.K., Marone, C. H., \& Thompsen, C.O. (2010). Developing then 21st-century leader. Achieve Global, 2 (1).

Taliadorou, N. \& Pashiardis, P. 2011. Examing the relationship of emotional intelligence and political skill with effective educational leadership styles. International Congress for School Effectiveness and Improvement 30.

Ugboro, I.O. 2006. Organizational commitment, job redesign, employee empowerment and intent to quit among survivors of restructuring and downsizing. Institute of Behavariol and Applied Management: 232-25. 